for success in this particular kind of craft. The paper was illustrated by a large number of drawings of various vessels.

A paper " On Registered Tonnages, and their Relation to Fiscal Charges and Design" was read by Mr. James Maxton. In this the author pointed out some of the absurdities and anomalies incidental to the present stage of the law in regard to the tonnage of ships. A long discussion followed, in the course of which many speakers gave expression to the opinion that a change in the law was absolutely necessary in the interests of shipowners, harbour authorities, and, also, passengers. Several shipowners who spoke laid it down as a principle that in cross-channel steamers every passenger should have a separate berth, and it was only the way in which tonnage was measured that prevented such a desirable feature being introduced.

Prof. W. H. Watkinson read a paper in which he described some new features of superheaters. He pointed out that, even with a separate condenser, and all the other improvements that have been made since the time of Watt, from 12 per cent. to 30 per cent. of the steam supplied to an engine is condensed during its admission to the cylinder. The steam turbine is the only engine in which this condensation of the steam by previously cooled surfaces does not take place, but the steam in turbines is wet from expansion while doing work. Liquefaction of steam may be reduced by steam jacketing; by compounding the cylinders; by steam separators; by a special arrangement for sweeping the condensed steam out of the cylinder at each stroke; by reduction of clearance surface; and by superheating. The last, the author said, was by far the most effective. During superheating, although the pressure of the steam remains constant, its volume is greatly increased. The amount of heat required to superheat ilb, of steam by $150^{\circ} \mathrm{F}$. is 72 British heat units; this is only about 6 per cent. of the heat required to generate $\mathrm{xlb}$. of dry saturated steam. The increase in volume due to this additional 6 per cent. of heat averages about 30 per cent. In some cases where superheated steam is used, the superheating is only carried so far as to reduce, or at most to annihilate, initial condensation. In these cases the steam, after it has been admitted to the cylinder of an engine, becomes ordinary saturated steam before or at cut-off, so that during expansion some condensation of steam takes place, due to work being done at the expense of the internal heat of the steam. There is, then, no advantage due to the increase of volume of the steam during superheating, but there is great saving in steam and in coal, due to the reduction of initial condensation and leakage of steam past the valves and pistons. In the case of large engines of the usual type, it is not possible to superheat the steam by more than $200^{\circ} \mathrm{F}$., and in some cases there is trouble with the valves if the degree of superheat exceeds $150^{\circ} \mathrm{F}$. With piston valves the limit can be considerably exceeded. The author next discussed the question of independently-fired superheaters, and those in which the apparatus is placed in the uptake of the boiler or is heated by gases from the furnace. A superheater to which a gas-producer was attached was also illustrated and described by the author.

In the discussion on this paper, Mr. A. F. Yarrow said that superheating was the direction in which engineers must look for improvement in the economy of the steam engine. The difficulty in lubricating the cylinders of steain engines had been spoken of, but it was well known amongst engineers that for years the torpedo boat builders had never used internal lubrication for the engines of the craft they built. It was interesting to note that water would ooze through places where steam would not pass, and for this reason piston valves might be worked with superheated steam without metal being in rubbing contact with metal. Mr. A. Morcom gave some particulars of a vertical engine in which superheated steam had been used. It was a $500 \mathrm{kw}$. engine, and the steam was at $600^{\circ} \mathrm{F}$. With saturated steam the consumption of water per kilowatthour was $2 \mathrm{Ilb}$.; with superheated steam it was r6lb.

During the stay in Belfast, the shipyard and engine works of Messrs. Harland and Wolff, and those of Messrs. Workman and Clark, were visited. There was a steamer trip down Belfast Lough, a reception at the harbour offices, and a dinner given by the Right Hon. W. J. Pirrie at his residence at Ormiston.
On Thursday, June 25 , members proceeded to Dublin, where they attended a garden party given by the Lord Lieutenant at the Vice-regal Lodge; rain entirely spoilt the pleasure of the reception. In the evening there was at ball at the Mansion House.

On the following day the members met in the lecture theatre of the Royal Dublin Society, when Mr. A. F. Yarrow, vice-president of the Institution, occupied the chair. A paper by the Hon. C. A. Parsons was first taken, the subject being "Modern Steam Turbines, and their Application to the Propulsion of Vessels." The paper was largely of an historical nature, and gave particulars of the various vessels in which the steam turbine had been fitted, such as the two unfortunate torpedo-boat destroyers, Viper and Cobra, which were both lost at sea. The King Edward and Oueen Alexandra were two passenger steamers that had been running successfully on the Clyde. The Queen is a cross-channel steamer, built for the Dover-Calais route, and has been put on her station since the paper was read. She has machinery of 8000 I.H.P. On her trial on the Skelmorlie mile she made a mean speed of $2 \mathrm{r} \cdot 73$ knots. Another boat of the same type, to be fitted with turbine engines, has been built for the L.B. and S.C.R., and will be put on the Newhaven-Dieppe route. She is 280 feet long and of 34 feet beam, and will shortly be launched. Three large yachts have lately been fitted with steam turbines, the largest being the Lorena, built by Messrs. Ramage and Fergusson, of Leith. She is 253 feet in length and of 33 feet 3 inches beam. The steam turbines in this vessel are similar to those of the King Edward and Queen Alexandra, but somewhat larger. The trial of the Lorena took place in the Firth of Forth in May, the speed attained being 18 knots. The turbine yacht, the Tarantula, built for the late Colonel McCalmont by Messrs. Yarrow and Co., was of the torpedo-boat type, but with somewhat heavier scantlings. She made 25.36 knots on her trial trip, her displacement being 150 tons. The Velox is a torpedo. boat destroyer recently purchased by the British Admiralty. She has machinery similar to that which was in the Viper, and will be capable of developing upwards of ro,ooo H.P. Two small triple-expansion reciprocating engines, each of I50 H.P., are fitted for cruising speeds up to 13 knots. The steam from these exhausts into the turbines, where its expansion is completed before it passes to the condensers. Another torpedo-boat destroyer, the Eden, will have machinery of 7000 H.P., and her speed will be $25 \frac{1}{2}$ knots; whilst a third-class cruiser, Amethyst, built for the British Government, will have turbines of 9800 I.H.P., her speed being $2 \mathrm{r}^{3}$ knots. The author looked forward to the time when steam turbines would be fitted to vessels of the largest size, such as Atlantic liners. The experience with the marine turbine up to 10,000 H.P. in ships of fast as well as of moc'erate speed had tended, he claimed, to justify the anticipation--guided by theory-that the larger the engines the more favourable would be the results as compared with the reciprocating engines. The saving in weight, space, attendance and power would be still more marked with turbine engines of above ro, ooo H.P., and up to 60,000 H.P., for which designs had been prepared.

The remaining paper read at the meeting was on the Dublin Harbour works, the author being Mr. J. P. Griffith. During their stay in Dublin the visitors took a steamer trip down the Dublin Bay, and on the evening of Friday the Institution dinner brought the meeting to a close.

\section{THE INTERNATIONAL CONGRESS FOR} APPLIED CHEMISTRY.'

\section{SO many papers on analytical methods were presented} that it is impossible even to enumerate them. The International Commissions on Analysis and on the Analysis of Fodders and Manures had not received all the reports yet which the Paris meeting had called for; the two Commissions over which G. Lunge presided-Maercker (Halle), chairman of the second Commission, having died-held some of their meetings jointly with sections i. (analysis) and vii. (agricultural chemistry). The proposals for a uniform method of drawing up analytical reports were made by W. Fresenius (Wiesbaden); Ch. Guillaume (Sèvres) reported

\footnotetext{
1 Continued from p. 158.
} 
on the mass of the c.c. of water and on thermometer scales.

Section ii. received some important communications on the auto-purification of waters. G. Weigelt (Berlin) has experimented on the rates of diffusion of refuse waters into river courses when introduced in different circumstances; tests based upon average contamination are quite misleading when injury to the fish is concerned. River water can, owing to its contents in carbonates, bind enormous quantities of sulphuric acid and also of alkalis, by decomposition of the bicarbonates, and iron salts are quickly deposited. F. Fischer (Göttingen) spoke on technically pure water, and regretted that biological tests seemed to supplant chemical analysis; the methods of sample taking were faulty, In section viii. Vandevelde (Gand) remarked that rest, absence of antiseptic and chemical compounds, presence of living organisms, and aëration favoured the auto-purification of water courses. Hygiene and navigation were in opposition; in flat country districts rivers should be doubled, a canal to serve for navigation, and the old bed for purification. Ch. Dreyfuss spoke on the septic tanks of Manchester, Proskauer and Erlwein on the ozonesterilisation plants of Siemens and Halske at Wiesbaden and Paderborn. On the suggestion of Klaudy (Vienna) it was resolved to bring the water question before the next congress.

G. Lunge reviewed the state of the sulphuric acid manufacture in a very able paper, recommending water-sprays (not vapour) for the lead chambers, and reaction plate towers with artificial draught, and pointing to the great improvements lately effected in concentration apparatus. Kestner (Lille) described his lead ventilators for artificial draught. E. Hart (Easton, Pa.) reported on sulphuric acid in the United States since 1900, and D. Pennock (Syracuse, N.Y.) on the progress in the soda industry in the United States. G. Beilby (Glasgow) reviewed the position of the cyanide industry, pointing out that the actual plants could supply more than twice as much cyanide as is wanted. Synthetic cyanide processes were further discussed, in different sections, by F. Rössler, G. Erlwein, and A. Frank. The latter two spoke particularly on the Caro-Frank process taken up by Siemens and Halske. The carbides of barium and calcium bind nitrogen when powdered and heated, forming $\mathrm{CaCN}_{2}$, which, on extraction with water, yields $\left(\mathrm{CN}^{2} \mathrm{NH}_{2}\right)_{2}$, and on fusion with salt (soda was used for the barium compound which was first prepared) sodium cyanide. The calcium cyanamide can also directly be prepared in the electric furnace from lime, coal, and atmospheric nitrogen. Decomposed with water vapour under pressure ammonia results; the calcium cyanamide also gives off ammonia in the soil, and is used as manure under the name of Kalkstickstoff. J. Bueb (Dessau) explained the recovery of the cyanogen from illuminating gas.

F. Mylius (Reichsanstalt) showed that the loss of weight which glass undergoes when treated with water would afford a basis for the classification of chemical glasses; an electric conductivity test practically gives the necessary data. R. Dralle described glass blowing machines Heinecke, recent improvements in keramics effected at the Royal Porcelain Manufactory of Berlin; Vogt (Sèvres) and Heintze (Meissen) also contributed communications on their porcelains. H. Heraeus, of Hanau, showed his new resistance furnaces, in which platinum foil $0007 \mathrm{~mm}$. in thickness is used instead of wire. The new iridium furnace, also shown, is an iridium tube $0.3 \mathrm{~mm}$. in thickness, which was directly heated by continuous currents up to $2000^{\circ} \mathrm{C}$. With the aid of these furnaces and the experienced glassblowers of Siebert and Kühn, of Cassel, quartz vessels are now made in Hanau. Ordinary quartz crucibles cost about half as much as platinum crucibles; they are attacked by metallic oxides and are permeable to hydrogen above $1300^{\circ} \mathrm{C}$. $\left(1100^{\circ} \mathrm{C}\right.$. according to Hahn), but do not crack on sudden cooling: water gas converts the quartz into tridymite. Siebert and Kühn had quartz thermometers on view. W. Hempel (Dresden) constructs simple high temperature furnaces by cementing small carbon rods to a zig-zag surrounding the crucible; the shell is iron lined with kieselguhr and carbon. Using an arc furnace and placing the substance in the cup of a hollow carbon rod, he has determined the following melting points:- magnesia, $2250^{\circ}$; lime, $1900^{\circ}$; alumina, $2068^{\circ}$; magnesite $2000^{\circ}$; porcelain (Berlin) softens at $155^{\circ}$; Meissen porcelain at $1850^{\circ}$. In these experiments a rod rests loosely on the substance, and breaks a contact when sinking. The temperature is determined with a Holborn-Kurlbaum optical pyrometer, or a Bunsen photometer of Hempel's, in which the rays are several times reflected: for this reason Hempel himself regards all these preliminary values as probably too low. H. Bunte (Karlsruhe) demonstrated with the aid of laboratory mantles that neither pure thoria nor pure ceria yield the high luminescence which we obtain by mixtures, and that very small percentages of uranium, platinum, \&c., in thoria also produce brilliant lamps, but that none of these are durable. The luminosity is probably simply physical, but there may be catalysis.

Section iija., metallurgy, discussed papers by $\mathrm{H}$. Wedding and Th. Fischer on metallic hydrides, by C. Schiffner (Freiberg) and A. Lodin (Paris) on pyritic smelting, by Ch. E. Munroe (Washington) on mining, metallurgy, and explosives in the United States, Gin (Paris), on extraction of copper pyrites with $\mathrm{SO}_{2}$, \&c. In section iiib. Brunswig, Bichel, Blochmann, Mettegang, Eschweiler, Watteyne, O. Guttmann (London), Knight (Krumel), Lenze, Bergmann and others had long discussions on the Trauzl lead block test, determination of explosive velocities, transport of compressed gases and liquids, protection of explosive works against lightning, danger from perchlorates in powder, \&c. O. Guttmann's proposal for an international committee on explosion tests in experimental mine galleries did not find sufficient support.

Section iva. had many good papers by C. Engler, Bergner (Baku), Aisinmann (Campina), E. O'Neill (California), Harperath (Argentina) on petroleum; Charitchkow (Grossny) proposed to fractionate technically naphtha in the cold by means of alcohol mixtures. Connstein (Berlin) described the successful splitting-up of fats by the enzymes contained in Rhicinus seeds, \&c.; Lewkowitch (London) referred to the same subject Other papers were on cyanogen, illuminating and water gas (Bunte and F Fischer), saccharin (Fahlberg), \&c.

Sections ivb., dyes; v., sugar; vi., fermentation and starch; vii., agricultural chemistry; viii., hygiene, pharmaceutical and medicinal chemistry, and foods; $x i .$, legal and economical questions, were all very busy.

Section ix., photochemistry, discussed papers by J. M. Eder (Vienna) and Ollendorf (Berlin) on sensitometers on latent images, by J. Waterhouse (Eltham) and Schaum (Marburg); on colour photography by additive synthesis, by $A$. Miethe and R. Neuhaus (Berlin); on photochemistry in the United States, the centrifugal bromide of silver, and other points, by L. Baekeland, Yonkers, N.Y.; on the resolution of the finest spectrum lines on Doppler's principle, by $O$. Lummer; and an exhaustive study of the dichroic fog, by A. Seyewitz (Lyon).

In section x., electrochemistry and physical chemistry, J. Traube and $G$. Teichner (Berlin) performed an experiment apparently disproving Andrews's views on the critical state of gases. A glass tube is partly filled with carbon tetrachloride; it contains also little spherical floats of glass of different densities. The tube is jacketed with paraffin and diphenylamine. When heated to and above the critical point, the meniscus disappears, and the floats do not all collect in the middle portion of the tube. This is to prove that there is no uniform density in the vapour. Repeating experiments of de Heen and Dwelshauvers-Dery, Traube considers that van der Waals's molecular gas volume constant $b$ is not constant, but increases when the liquid passes into the gaseous state, and that the vapour contains liquidogenous and gasogenous molecules the proportions of which depend upon the temperature. At the critical temperature both molecules are soluble in one another in any proportions.

W. Nernst (Göttingen) showed an apparatus with the aid of which he has determined the vapour densities of $\mathrm{CO}_{2}$ with $0.3017 \mathrm{mg}$., of $\mathrm{NaCl}$ with o $16 \mathrm{mg}$., of $\mathrm{S}$ with $0.57 \mathrm{mg}$. of substance. The substance is brought in an iridium vessel, which is lowered into a tubular iridium furnace of Heraeus and heated up to $1950^{\circ} \mathrm{C}$. The weighing is done on a balance, consisting of a capillary glass tube as beam, bent down at the end to serve as pointer, and resting on a quartz thread; this balance weighs to $0.001 \mathrm{mg}$., and can be loaded with $2 \mathrm{mg}$. maximum. The values found 
are, e.g. $\mathrm{H}_{2} \mathrm{O}_{17} \cdot \mathrm{I}$ (instead of 18 ), $\mathrm{CO}_{2} 42 \cdot 9$ (44), $\mathrm{S}_{3} 6$ and $37.7\left(3^{2}\right)$, so that the sulphur would appear to be monatomic at that high temperature.

E. Wedekind (Tübingen) produces colloid zirconium by reducing the oxide with magnesium and extracting with hydrochloric acid; O. Burns (Boston) colloids of paper, oxides, sulphides, \&c., by shaking them for many hours. Monti (Turin) spoke on the concentration of solutions, perfumes, wines, and ordinary salts by freezing; the acids and salts collect in the microscopical interstices between the small ice crystals, and when frozen blocks are left to themselves, the substances diffuse downward; concentration by cold is more economical than by heat. Bredig (Heidelberg) and Count Schwerin (Höchst) spoke on electric osmosis, E. Solvay (Brussels) on a gravitation formula applicable to diffusion phenomena, Zengelis (Athens) on the production of very high temperatures by burning aluminium in oxygen and other gases. The kinetics of the catalytic sulphuric acid process were discussed by Knietsch (who has worked the process out in Ludwigshafen) in section ii., and by Bodenstein and Bodtänder in $x$. Similar papers were read by Schenck (Marburg) on the splitting of $\mathrm{CO}$, by $\mathrm{H}$. Goldschmidt (Christiania) on the kinetics of reductions, by Bodländer on technical catalysis. H. Goldschmidt (Essen) reported on the manufacture of steel in the electric furnaces of Stassano, Gin-Leleux, Héroult, Keller, Kjellin, and others; Bancroft and A. A. Noyes on electrochemical research in the United States; Fr. Foerster (Dresden) and Brandeis (Aussig) on electrolytic preparation of inorganic compounds; $M$. Le Blanc (Karlsruhe) spoke on electrolysis with alternating currents and the possibility of determining the velocity $\mathrm{O}^{+}$ ionic reactions: Coehn (Göttingen) on electrode influence in electrolytic oxidations and reductions, H. Moissan on metallic carbides, Heroult on the efficiency of electrolytic soda processes, Danneel and Nissenson on the electrolytic deposition of metals, Küster (Clausthal) on dissociation pressure of soda solutions, W. Marckwald on his radioactive tellurium, and Precht (Hanover) on the spectrum and atomic weight of radium (in ix.). W. von Bolton demonstrated what he briefly calls luminosity of the ions. When a carbon rod is lowered as anode into sulphuric acid, containing a copper spiral as kathode, the rough surface of the carbon becomes at once bright under the influence of currents of nio volts. When rods of metals (or of carbon) are dipped into solutions of their salts, the rod being the kathode, a platinum spiral the anode, the rod begins to glow in brilliant colours, and beautiful band spectra of the ions (?) are obtained, differing from the spark spectra which result when the anode is glowing. The discussions were very good.

H. BORNS.

\section{SOUTH-EASTERN UNION OF SCIENTIFIC SOCIETIES.}

THE eighth annual congress of the South-Eastern Union of Scientific Societies was held at Dover on June I I-I3. A lively address by the president, Sir Henry Howorth, F.R.S., put pin pricks into all the infallibilities, begging the student to accept no predominant hypothesis without demur, to resist the fascination of great names, to challenge the exactness even of the exact sciences. Fallacies might often lurk in phrases, as when "the survival of the fittest" was glibly used to mean nothing more than the survival of the survivors. The address impressed its hearers with the advantage which every branch of science might derive from the touch of a keen and active critical faculty, working outside the ranks of the specialists.

The papers contributed to the congress fall into three classes, the purely local, the general, and those of divided interest. In the last of these Mr. A. T. Walmisley's essay discussed the methods by which a traveller between Kent and the Pas de Calais might cross the intervening strip of shallow water, on, in, under, or over it, without the in cidents which now so often befall him when the "silver streak" is converted into a tumultuous concourse of atoms. The new turbine steamer was indicated as the best chance fo: humanity - at least until something better is invented. Mr. W. Whitaker, F.R.S., observed that clearly nature had expressly designed the Straits of Dover for a submarine tunnel, though politicians might think otherwise. Mr. A. O. Walker, dealing with the effects of climate on dis- tribution, compared his long experience of the fauna and flora of Cheshire and North Wales with his later observations while residing near Maidstone.

Of local papers the most important was that by $\mathrm{Mr}$. Sydney Webb and Captain McDakin on the disappearing fauna and flora of the district. There were many lamentable and in part unavoidable losses. The dwindling of the colony of seals at Beachy Head was deplored, but no tears were seen to fall at the news that vipers were becoming scarce and polecats scarcer. The congress museum was instructively adorned by Mr. Webb's fine collection of Lepidoptera with their caterpillars, and by the display of plants with their seedlings from the Catford Society.

Prof. Boulger opened a discussion on the best means of checking the extermination of British plants and animals. Dr. Rowe, in a paper on the importance of zonal distribution, alluded to the doctrine that the souls of good geologists go hereafter to their favourite "sections," and hoped he might be allowed to stake out his claim to a particular slice of Dover Chalk, from which he had already abstracted about 5000 fossils.

The non-local discourses included an interesting account by the Rev. R. A. Bullen of " a late Celtic cemetery at Harlyn Bay," and a valuable investigation by Miss Ethel Sargent, who unfolded the story of Geophilous plants, explaining how these "lovers of the soil," to suit seasons and climates, for periods of varying duration, keep themselves close within the protecting bosom of their mother earth, the seeds and bulbs in the meantime, with a kind of vegetable instinct, ever using their foodstore to the best advantage. The concluding address was by Dr. Jonathan Hutchinson, F.R.S. the retiring president, who at two successive congresses has delighted his audience by a finelyargued discussion of a subject not at the first blush very attractive. His theme was leprosy. His theory is now well known, that this disease is caused by the consumption of badly cured fish, or occasionally by the eating of food which has been handled by lepers. During the last two years he has visited Africa and India, everywhere seeking out lepers and leprous communities, especially in places where ho had been told that a fish diet was out of the question. Everywhere he found that in that particular his informants had been misinformed. A quotation from Erasmus sent to Dr. Hutchinson by a classical friend represented the Pope himself as proposing to proscribe the use of salt fish on account of its supposed tendency to spread leprosy, though it is not salt fish in itself that lies under any evil imputation. Erasmus often makes ironical statements, but on the foul effects produced in his day by the consumption of putrid fish his dialogue "Ichthyophagia" speaks with no ambiguity.

\section{UNIVERSITY AND EDUCATIONAL} INTELLIGENCE.

OXFORD.-The following is the text of the speeches delivered by Prof. Love in presenting $M$. Poincaré and Prof Story-Maskelyne for the honorary degree of D.Sc. at the Encænia on June 24 :-

Nescio an maximus inter mathematicos qui nunc vivun sit Henricus Poincaré : vir iure mirandus non solum quod novis viis quærendi usus novos fructus adeptus est, sed quod tot et tam diversa doctrinæ genera unus complect potuit, cum commentariis innumerabilibus fere omnes geometrices et analyseos partes illustraret. Cum in hæc recondita doctrinæ arcana altius penetrasset, rite eum Regalis Societas ornavit numismate aureo in memoriam Professoris nostri Sylvester instituto quod ei primo datum est. Non solum subtilissimis illis quæstionibus quæ de mathematica veritatis natura inter philosophos oriuntur hunc auctorem plerique sequuntur, sed ingenii maximi viribus nisus de luce, de vi electrica, de difficillimo quoque doctrinæ genere præclarissime disseruit. In Astronomia certe er de motu et de figura planetarum est commentatus ut omnibus de hac re quærentibus nova quadam et meliore via insistendum sit. Hunc talem virum in omni genere doctrinæ insignissimum, rerum naturam animo peragrantem, geometren, physicum, astronomum præstantissimum, Academia nostra inter suos doctores libentissime adscribit.

Septem et quadraginta abhinc annos Willelmo Buckland

No. I 757 , vOL. 68] 